\title{
Recent trends and activities in hydrogeologic research at the University of Miskolc, Hungary
}

\author{
Tamás Madarász*, Péter Szúcs, Balázs Kovács, László Lénárt, Zoltán Fejes, \\ Andrea Kolencsik-Tóth, István Székely, László Kompár, Imre Gombkötő
}

University of Miskolc, Miskolc, Hungary

Received: January 28, 2015; accepted: January 28, 2015

The Institute of Environmental Management at the University of Miskolc, as a major Hungarian research entity in groundwater management, is dedicated to finding solutions to regional issues of global sustainable water resource management challenges, thus further developing its scope of groundwater management competence. WELLaHEAD is an EU-funded fundamental research program coordinated by the faculty members of the institute, covering a broad spectrum of relevant groundwater related research topics based on Northern Hungarian test sites. The research concept is described in the detailed Research Plan of the project, and after 14 project months some of intermediate results can be presented from three research modules.

Keywords: hydrogeological research, northeastern Hungary, project WELLaHEAD, geothermal potential, Tokaj mountains, groundwater recharge, contaminant transport

\section{Introduction}

The Department of Hydrogeology and Engineering Geology of the University of Miskolc is a leading research entity in hydrogeology in Central and Eastern Europe. In its latest research project, WELLaHEAD, the team has dedicated its efforts to a complex research agenda related to various quantitative and qualitative groundwater management issues. The test areas are research sites from northeastern Hungary, one of Europe's least developed regions; however, some of the research results have a

\footnotetext{
* Corresponding author: Egyetem út, H-3515 Miskolc, Hungary;

E-mail: hgmt@uni-miskolc.hu
} 
much broader impact on groundwater management, monitoring, contaminant transport and site remediation.

A remarkable milestone of modern hydrogeology was the introduction of the local and regional groundwater flow systems theory, published by Joseph Tóth in 1962. The theory has been proved to be applicable in several case studies at many sites on the globe including the Great Plain of Hungary (Tóth 1962, 1978; Tóth and Almási 2001). The planned fundamental research plan of the project mainly covers the engineering and water management aspects of the flow system theory applications. We also cover issues such as sustainable thermal, mineral, cure, and drinking water management, anthropogenic effects on groundwater resources, ecohydrogeology and complex multidisciplinary research of porous and karstic aquifers (Szücs et al. 2012).

The research goals of the project have been structured around five topics (i.e. research modules; Fig. 1):

1. Complex hydrogeologic research on mineral, cure, and thermal water investigation and utilization in northeastern Hungary - The research led by the Institute of Environmental Management includes the setting up and calibration of a regional-scale flow and heat transport model at a selected location in northeastern Hungary. The model will be capable of giving accurate information on mineral, cure, and thermal water resource characterization, the simulation of real and assumed consumption scenarios, and of fine-tuning water balance equations.

2. Better understanding of the interaction between cold and warm karst water bodies - The Bükk karst system monitoring network has been operating for 20 years, playing an important role in predicting water resource quantities for Miskolc and several other stakeholders of the system. The monitoring system can also contribute to the better understanding of cold/warm water-body interaction.

3. Investigating the quantitative and qualitative impact of mining activities on groundwater resources - Many settlements are impacted by abandoned mining sites, mining waste piles and tailings where the impact of infiltrating water and the compatibility of tailings material and groundwater resources were not assessed. There is a rising demand to find new solutions to decrease the impact of open pit mines on shallow and deeper groundwater resources, by decreasing the amount of dewatering volumes.

4. Better understanding of transport phenomena of special contaminants the specific behavior of contaminants in the subsurface environment must be better understood by more advanced modeling tools and new types of laboratory analysis. The 4th module is dedicated to testing new methods for modeling, measuring and monitoring.

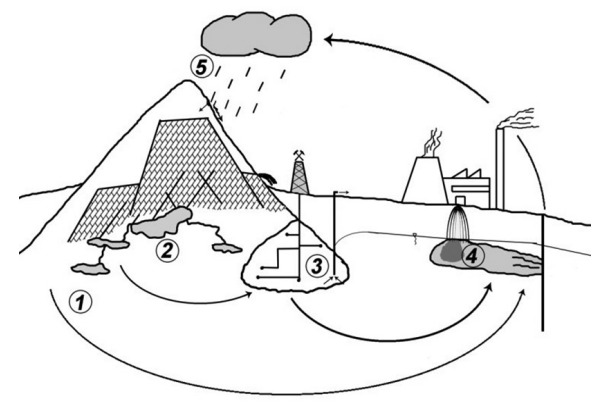

Fig. 1

Research modules of the project and their connection to the flow system theory concept 

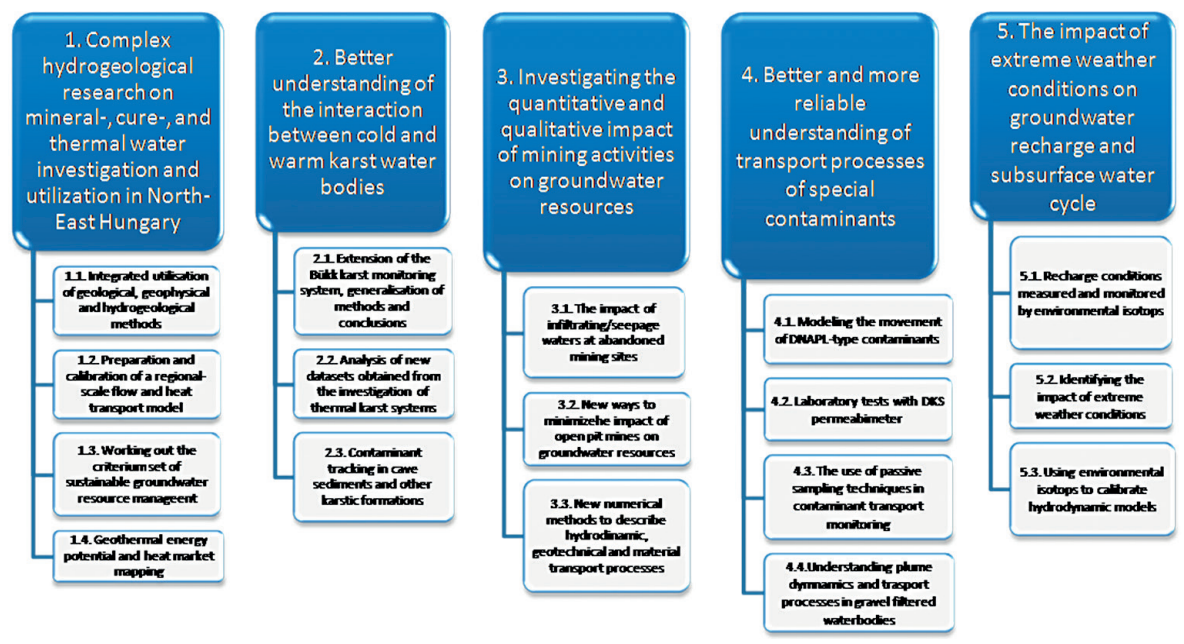

Fig. 2

The five research modules of project WELLaHEAD and the involved R\&D ideas

5. The impact of extreme weather conditions on groundwater recharge and subsurface water cycle - The fifth research team will investigate the impact of extreme weather conditions (f.i. intense precipitation events) on the recharge of shallow groundwater bodies. They will evaluate the possible use of environmental isotopes as calibration tools for contaminant transport models.

Each module set up its research teams working on 3-4 R\&D ideas (Fig. 2) involving more than 70 researchers altogether. Beside the five research modules the project aims to develop its own technical knowledge transfer concept (module 6). Some of the research results are being utilized via direct industrial partnership (e.g. patents, technology developments) while others will be further developed through the international networking activity of the project and through the formulation of new proposals in the Horizon2020 calls, starting from 2014.

This paper intends to introduce some interim results obtained from some of our research activity. The highlighted results are chosen by random selection from the project's research agenda.

\section{Results and Discussions}

\section{Hydrogeological and geothermal research in the Szerencs area}

The Tokaj Mountains are one of Hungary's best-known volcanic areas, at the northeastern edge of the country. Hydrogeologic research aiming at thermal water resources of the region has never been a priority for the Hungarian Hydrogeological Society. The area has a very complex geological setting. Due to uncertainty in the composition and 


\section{T. Madarász et al.}

depth of the basement rock and the rather low number of deep boreholes reaching it, it is a rather difficult task to investigate the potential of available hot water resources (Fejes et al. 2013). Several warm and hot water wells had been drilled in the Tokaj Mountains providing steady discharge with stable water quality and temperature (Miklós 2003). Szerencs is a town of 10,000 inhabitants located in the southern part of the mountainous area. In 2011 the local municipality of the town expressed its interest in thermal water research activity, which was further extended to deeper geothermal research and utilization of excess residual heat and other heat utilization concepts. The research concept was established with the prior knowledge of previous geophysical measurements, the geologic and hydrogeologic data of existing wells in the region, former pumping test data and other historical data and maps of the site.

The geologic structure of the site is mainly influenced by volcanic activity of the Miocene, characterized by several sequences and vast volumes of pyroclastite layers and other volcanic materials. Most of the mountains of the region form part of these geologic structures. Their thickness is unknown because the deep boreholes aimed at reaching the basement rock (e.g. Tállya-15, depth: 1,200 m) have never reached the bottom of the Miocene volcanic sequence. Volcanic activity ceased at the end of the Sarmatian, and gave way to intense post-volcanic phenomena. The magmatic
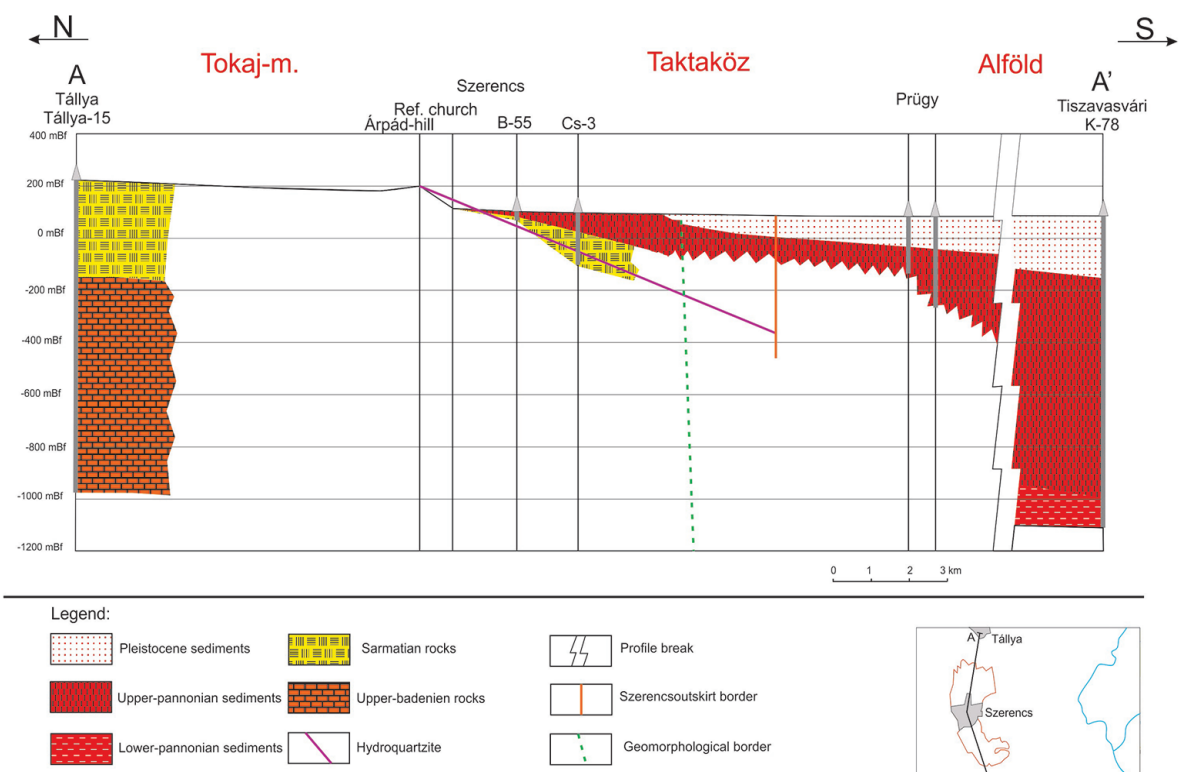

Fig. 3

Geological cross-section of the Szerencs study area 
intrusions warmed up the groundwater and their high silica content, which reached the surface and flowed through hot water springs, meanwhile forming hydroquartzite bodies that even today indicate the main flow paths.

The geologic and hydrogeologic profile of the Szerencs area was created within the project (Fig. 3). The Pannonian layers can only be found in the southern part of the area. The extents of the Miocene and Sarmatian layers are not known; however, the direction of the hydroquartzite layers can be estimated, which are the relevant tepid water aquifer in the region.

The geophysical measurement points were located using the drawn geologic section (Fig. 4). Using the Vertical Electrical Sounding (VES) method one can observe the topography of the volcanic lava rock surface and can locate possible faults within the aquifer. Geophysical measurements were implemented using 22 geoelectrical points, with an approximately $500 \mathrm{~m}$ penetration.

Data were interpreted using 1, 1.5, 2 and 2.5-dimensional geophysical interpretation methods and we thus obtained the volcanic base level surface map. This method, and the aeromagnetic geophysical map, provided good correlation and the negative magnetic anomaly located therein indicates the fault zones in the site.

Several of the 50 wells on the site have reached these fractured quartzite layers formed by the region's post-volcanic activity. The formation has remarkably more favorable hydrogeologic features and parameters than its geologic environment (Fig. 5). Most of the wells screened on this aquifer have good well hydraulic and temperature properties (Table 1).

Table 1

Water wells and their parameters on the study area

\begin{tabular}{llllll}
\hline Name & $\begin{array}{l}\text { Depth } \\
\text { of screening } \\
{[\mathrm{m}]}\end{array}$ & Material of aquifer & $\begin{array}{l}\text { Yield } \\
{[1 / \mathrm{min}]}\end{array}$ & $\begin{array}{l}\text { Temperature } \\
\text { of effluent water } \\
{\left[{ }^{\circ} \mathrm{C}\right]}\end{array}$ & $\begin{array}{l}\text { Location } \\
\text { on geophysical } \\
\text { map }\end{array}$ \\
\hline Ny & $184-194$ & Sarmatian hydroquartzit & 1200 & 25 & - \\
\hline $\begin{array}{l}\text { Chocolate } \\
\text { factory-3 }\end{array}$ & $180-195$ & hydroquartzit complex & 660 & 26 & REF3 \\
\hline $\begin{array}{l}\text { Chocolate } \\
\text { factory-2 }\end{array}$ & $185-195$ & siliceous tuff & 100 & 16 & 1 \\
\hline $\begin{array}{l}\text { Motel Fridez } \\
\text { Sugar factory-1 }\end{array}$ & $180-204$ & Miocene hydroquartzit & 1300 & 24 & - \\
\hline $\begin{array}{l}\text { Waterwork well } \\
\text { in Szerencs }\end{array}$ & $18-22$ & fractured hydroquartzit & 400 & 15 & - \\
\hline $\begin{array}{l}\text { Thermal well } \\
\text { fractured limnoquartzit }\end{array}$ & 2340 & 19 & - \\
\hline $\begin{array}{l}\text { Waterwork well } \\
\text { in Bekecs-3 }\end{array}$ & $33-41$ & rhyolit tuff with & 20 & - & REF1 \\
\hline $\begin{array}{l}\text { Waterwork well } \\
\text { in Bekecs-4 }\end{array}$ & $37-60.3$ & Miocene hydroquartzit & 1560 & 21 & - \\
\hline
\end{tabular}




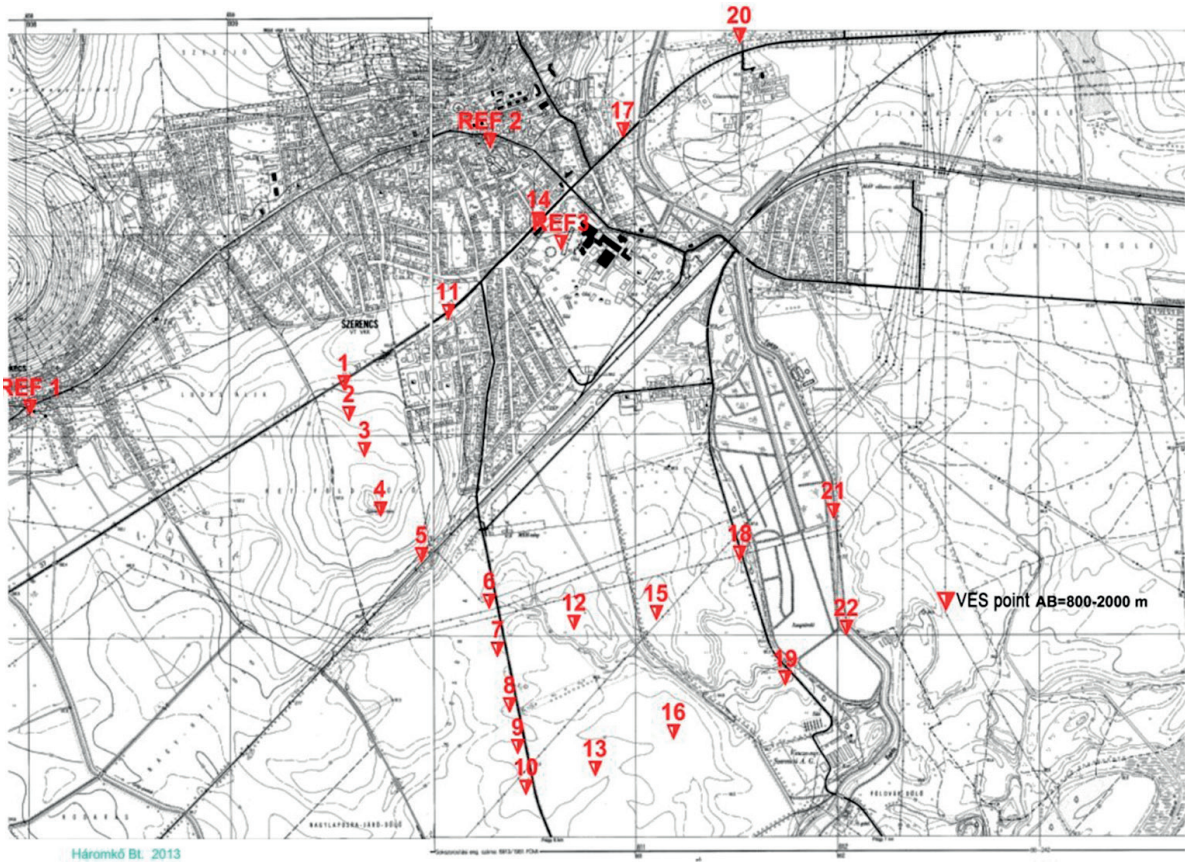

Fig. 4

Points of the new geophysical measurement campaign

During the field campaign 30 wells and 20 springs of the region were sampled (Fig. 6). Springs were sampled and on-site temperature, conductivity and discharge measurement were carried out. As for wells water sampling, discharge measurement, temperature data (bottom and outflow) measurements and pumping tests were conducted.

The general water chemistry protocol was analyzed in the laboratory of the University of Miskolc, Department of Hydrogeology and Engineering Geology. Trace elements and components were analyzed in an accredited external laboratory. The obtained water chemistry data plus additional isotope chemistry measurements were useful in identifying chemical composition and the geographic position of discharging hot water anomalies along major structural faults.

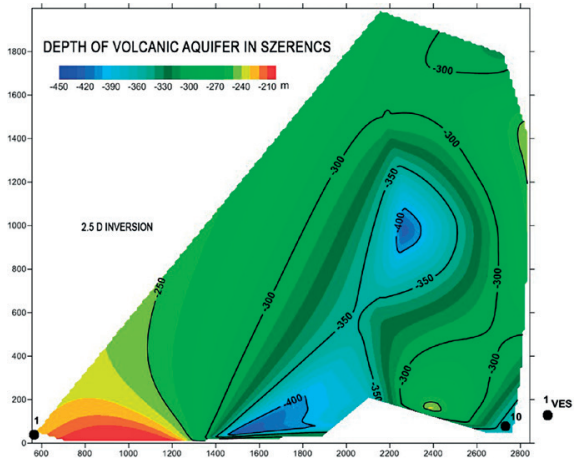

Fig. 5

Depth of volcanic aquifer in the Szerencs area using 2.5 inversion method 


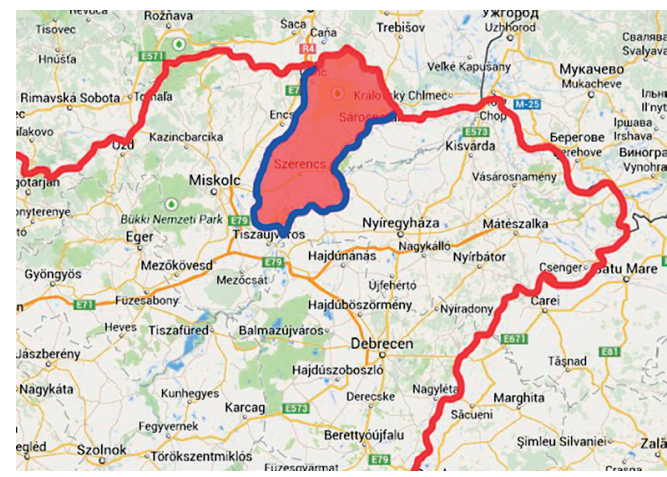

Fig. 6

Sampling site of geothermal research in the Szerencs area

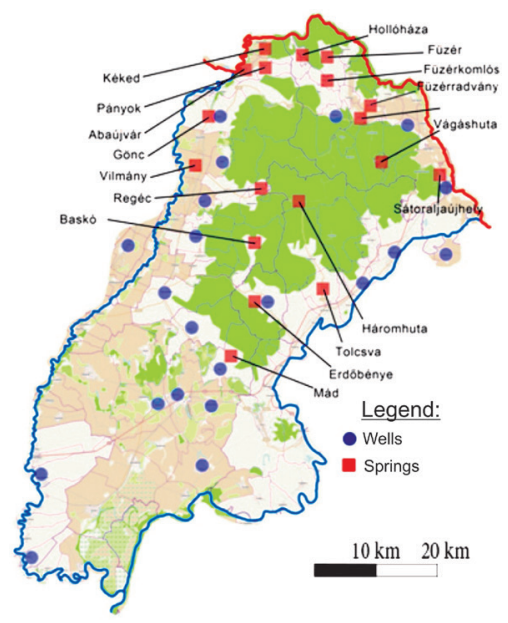

With this analysis we could delineate the eastern and western structural fault zone of the region, which will help the exact siting of the new wells.

All the collected hydrogeologic, geophysical, and geologic information was organized into a unified database. Part of the database is the hydrogeologic and water chemistry data of wells and springs of the site, also including measurements form the past 50 years. The analysis of these data provides new insight into the subsurface flow system of the Tokaj Mountains, and provides remarkable new information for a future geothermal project. A unique finding of the analysis is the Pányok warm water occurrence where naturally discharging water, with temperature over $30{ }^{\circ} \mathrm{C}$ was described. Geoelectrical and magnetic measurements were conducted on the site, and the fault zone responsible for the Szerencs warm water anomaly was spotted. With the achievement of having pinpointed the known location of the discharge zones, the siting of new wells is on the horizon.

\section{Investigation of contaminant transport in riverbank aquifers}

An industrial site located along the Danube River in the northern part of Hungary is under detailed investigation by our research team within the framework of the "WELLaHEAD" project. The main goals of the research are to better understand the contaminant transport phenomena in soil and groundwater influenced by surface water, and to predict the behavior of contaminant plumes in riverbank aquifers. Based on the results it will be possible to design a future site remediation process more accurately at the test site.

Considering that the dynamics of the contaminated groundwater are strongly dependent on the actual state of the flow system, as the first step of investigation considerable effort is put into describing the time and space-variable flow field. More than 
100 monitoring wells were installed and operated by the authorities to continuously record the groundwater head fluctuations in the investigated region. The wells are screened to the shallow part of the aquifer. The ground water levels are recorded daily since the 80 s of the last century. There are also daily river level data from the gauging stations of the river. A monitoring system with 12 wells also exists around the contaminated site at 10 to $200 \mathrm{~m}$ distance from the river, in which dataloggers were installed within the framework of the project. A database with recorded head data of the monitoring systems was created, which provides enough information to describe the hydrodynamics of the groundwater-surface water interaction in the region. The evaluation of head data consists of the following parts: analyze the effect of river flood on the groundwater head, determine the distances of river effects in head, flow directions, and flow velocities, correlation between the river and ground water. Figure 7 shows some head characteristics along a perpendicular segment in a flood and in a dry period of the plotted years.

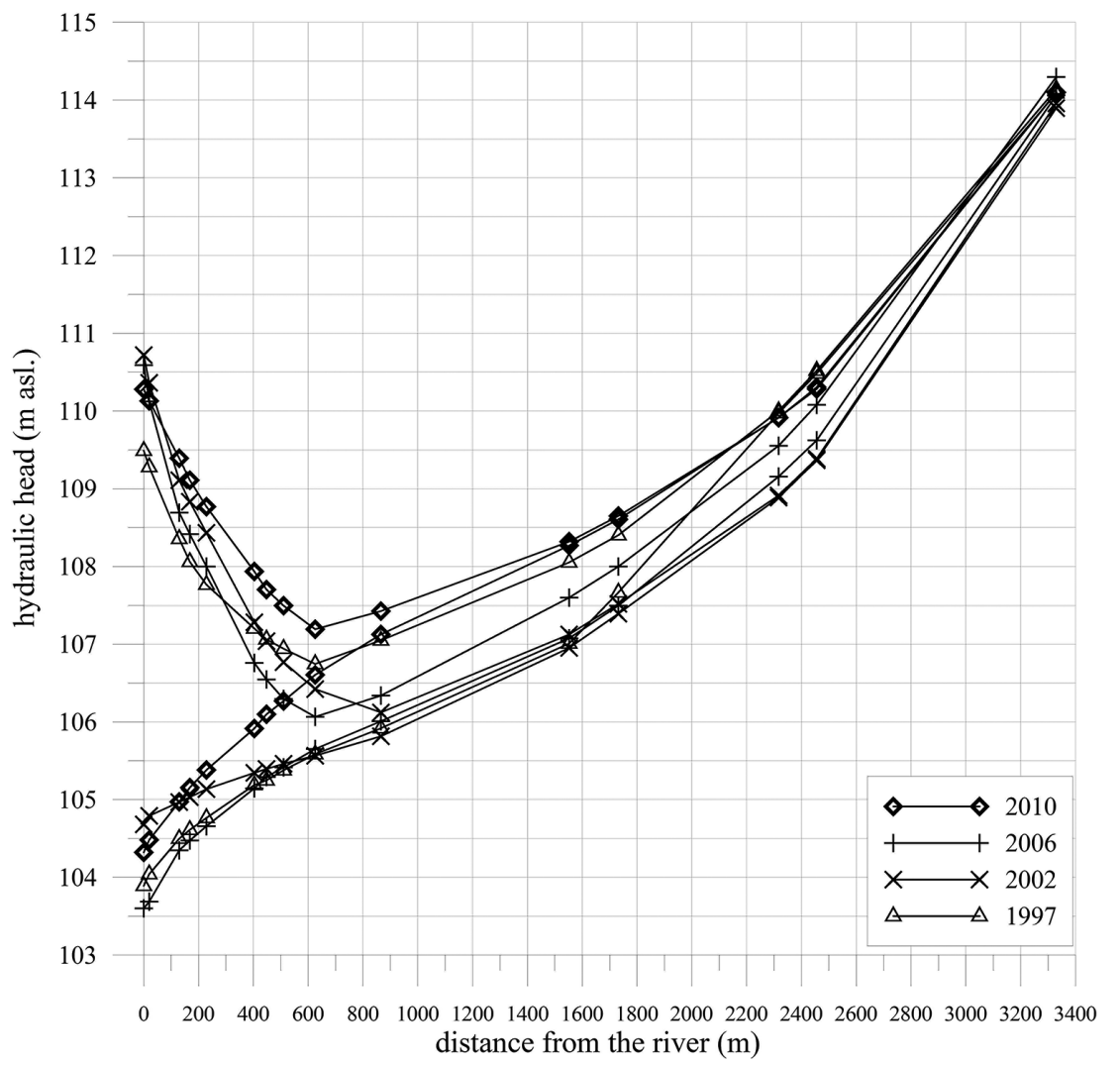

Fig. 7

Measured ground water head in two flow states with the distance from the Danube 
In field measurement campaigns a geoelectrical resistivity survey using Vertical Electrical Soundings (VES) measurement was carried out to determine the stratification of the upper $20 \mathrm{~m}$ of alluvial sediments. The geoelectrical sections obtained from the measurements were correlated with borehole data and a $3 \mathrm{D}$ geologic model was created for the region. During the field campaigns pumping tests were also performed in order to obtain the hydraulic parameters for the sandy gravel part of the aquifer.

An important point of the investigation was to survey the quality and degree of the contamination. In addition to water samples taken from the monitoring wells, continuous biochemical monitoring was applied and tested with passive sampling devices. The applied DGT (Diffusive Gradient in Thin films)-type passive samplers accumulate dissolved substances in a controlled way, and analysis in the laboratory provides the in situ concentration at the time of deployment (Davison and Zhang 2012). The resulting information is the biologically relevant (bioavailable) concentration of pollutants contrast to the conventional sampling techniques.

To observe the spatial distribution of contaminant plume in the aquifer, the IP (Induced Polarization) geophysical method was successfully applied. The measurements were repeated twice: in a wet spring period and in late summer of 2013. Between the two periods there was $4 \mathrm{~m}$ difference in the river head, which led to different hydraulic and contamination state of the aquifer. Based on the TAU-transform of the field measured Time-Domain IP data, the quality, degree and distribution of contaminants were determined (Turai et al. 2014). In certain parts of the site the dilution of groundwater was clearly detected in decreasing IP signs in the wet season, while in the dry season the method showed the accumulation of the contaminants in the aquifer; however, upsection from the source the results were the opposite. Next to the contaminant source the higher groundwater level results in higher contamination because of more intensive leakage from bottom of the tailings (Fig. 8). There was also difference in the distribution of the plume between the two measurements, and based on the results back and forth movement of the plume was recognized.
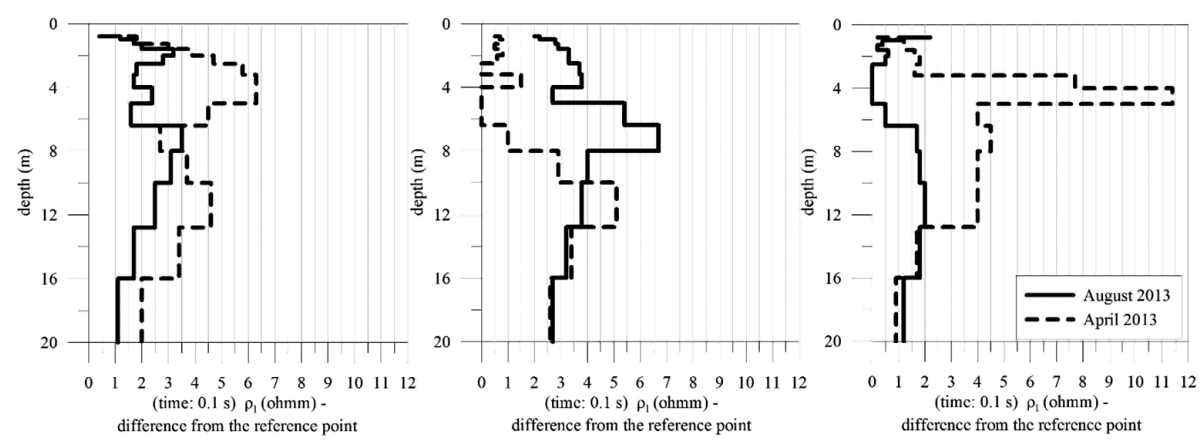

Fig. 8

The relevant IP signs (compared to the reference point) in three different parts of the contaminated site 


\section{Passive AMD treatment technology - pilot test}

One of Northern Hungary's abandoned ore mines is undergoing a complex rehabilitation program, which involves the passive acid mine drainage treatment pilot site at one of the former mine shafts. The effluent water is characterized by acidic $\mathrm{pH}$ level ranging between 2-4 and high dissolved metal contents ( $\mathrm{Fe}(\mathrm{II})$ concentration) varying from $589-914 \mathrm{mg} / \mathrm{dm}^{3}$ and $\mathrm{Cu}$ concentration ranging up to $30 \mathrm{mg} / \mathrm{dm}^{3}$. The discharge is moderate, ranging between $1.5-2.5 \mathrm{~m}^{3} /$ day, but even with the limited discharge it causes significant environmental load on the area. The operator of the site decided to develop a passive treatment technology and our research team offered a feasible technology as a test operation.

The designed system was based on previous research using lignite as a reactive barrier material (Bőhm et al. 2003; Madarász et al. 2011) and on preliminary lab measurements of both the hydraulic parameters and chemical functionality of the applied materials. For the adsorption of high heavy metal content of the drainage, lignite reactive material was applied. Literature studies showed that lignite has favorable properties and its adsorption capacity can reach up to $30 \%$ of that of active coal (Lakatos et al. 2007) while its cost is an order of magnitude lower. Also, the expensive regeneration costs can be eliminated if the exhausted lignite material is reused. After testing several options the team concluded that a grain size of 11-22 mm is appropriate to meet the hydraulic demand on the site test. A $56 \mathrm{~m}$-long concrete test channel was installed at the site which was separated into three cascades to sup-
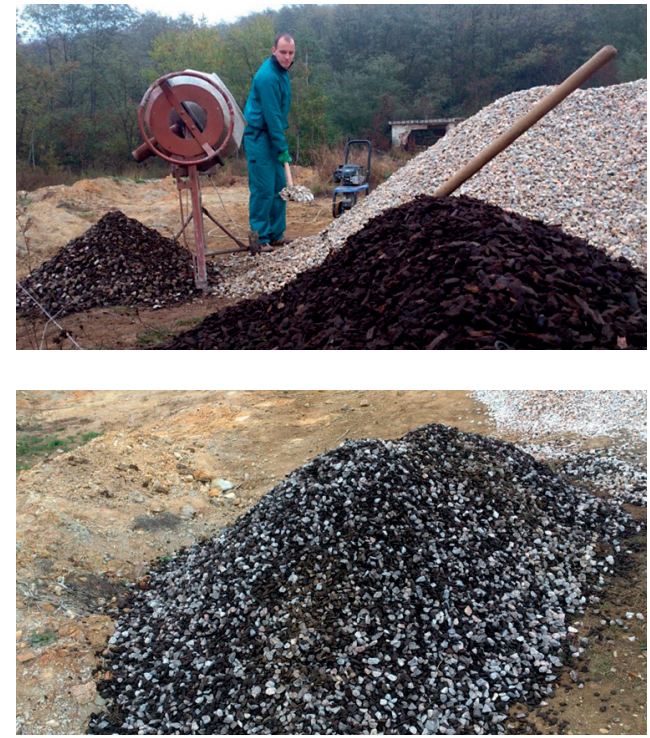

Fig. 9

Materials used in the passive AMD treatment pilot test

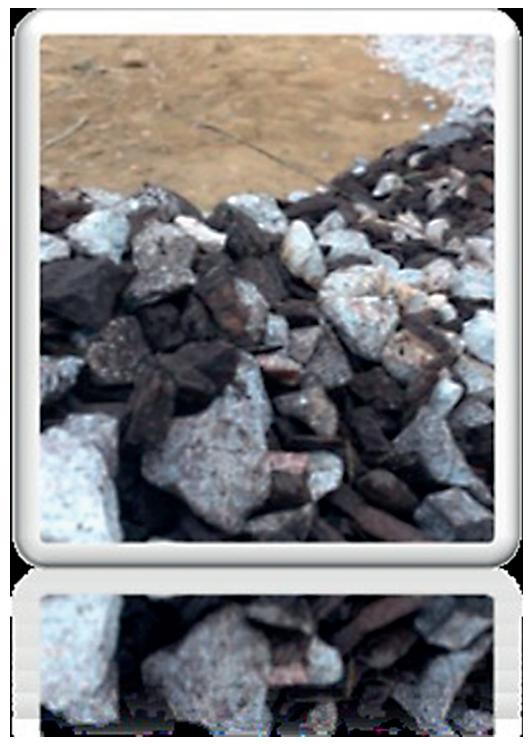




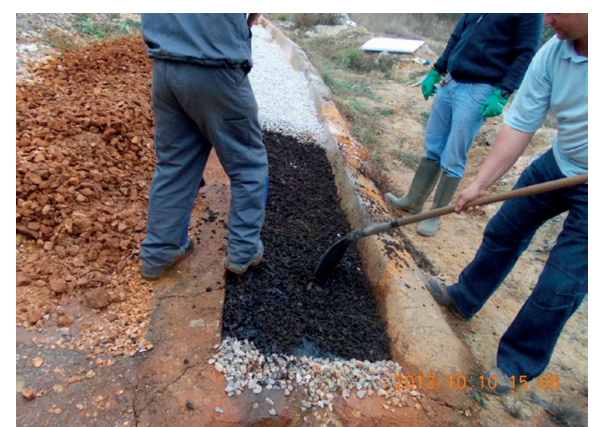

Fig. 10

Installing the passive AMD treatment channel

port the treatment technology steps. The system consisted of 3 successive steps: $1^{\text {st }}$ step: 40 m-long neutralization section filled with limestone (11-22 $\mathrm{mm}$ grain size); $2^{\text {nd }}$ step: $8 \mathrm{~m}$-long section with a $1: 1$ mixture of limestone and lignite (11-22 $\mathrm{mm}$ grain size); $3^{\text {rd }}$ step: $8 \mathrm{~m}$-long lignite field for adsorption of dissolved metals (Figs 9 and 10). During installation of the on-site test operation, deflector walls were placed in the channel to increase the interaction time between the drainage and reactive material.

The performance of the treatment technology was monitored by installing sampling points and on-site passive samplers at various points of the system and in the discharging stream. Water samples were analyzed in laboratory for the relevant metal content of the drainage water (Al, Fe, Cu, Ca, Mg, Zn, Ni, Pb, As, Cd). Table 2 and Fig. 11 shows the change of iron and copper concentration at two sampling time and four sampling points along the system.

Table 2

Summary of lab results for $\mathrm{Fe}$ (II) and $\mathrm{Cu}$

\begin{tabular}{|c|c|c|c|c|}
\hline \multirow{3}{*}{$\begin{array}{l}\text { Sampling point along } \\
\text { the technology canal } \\
\text { [m] }\end{array}$} & \multicolumn{4}{|c|}{ Time of sampling } \\
\hline & \multicolumn{2}{|c|}{ 22.10.2013. } & \multicolumn{2}{|c|}{ 15.11.2013. } \\
\hline & $\begin{array}{l}\text { Concentration } \\
\text { of } \mathrm{Cu}[\mathrm{mg} / \mathrm{l}]\end{array}$ & $\begin{array}{l}\text { Concentration } \\
\text { of } \mathrm{Fe}(\mathrm{II})[\mathrm{mg} / \mathrm{l}]\end{array}$ & $\begin{array}{l}\text { Concentration } \\
\text { of } \mathrm{Cu}[\mathrm{mg} / \mathrm{l}]\end{array}$ & $\begin{array}{l}\text { Concentration } \\
\text { of } \mathrm{Fe}(\mathrm{II})[\mathrm{mg} / \mathrm{l}]\end{array}$ \\
\hline $0+000$ & 21.65 & 1098.5 & 20.65 & 1039.5 \\
\hline $0+040$ & 20.55 & 816.5 & 21.5 & 1033.5 \\
\hline $0+048$ & - & - & 17.55 & 748.5 \\
\hline $0+056.5$ & 3.65 & 555.5 & 18.6 & 742.5 \\
\hline
\end{tabular}

The obtained results demonstrate the decreasing concentration of both components along the treatment channel. The concentration of iron decreases through the full length of the channel, while in the case of cupper only the last lignite-based section was effective.

The background for this phenomenon is due to the increase of $\mathrm{pH}$, which causes $\mathrm{Fe}(\mathrm{II})$ to be already transformed and precipitated as $\mathrm{Fe}(\mathrm{III})$ in the first half of the treatment channel. In the second half adsorption can further decrease the concentration thanks to the lignite barrier. The change in trends between the two-time periods is due to decreased performance of the treatment technology barrier. Several factors 

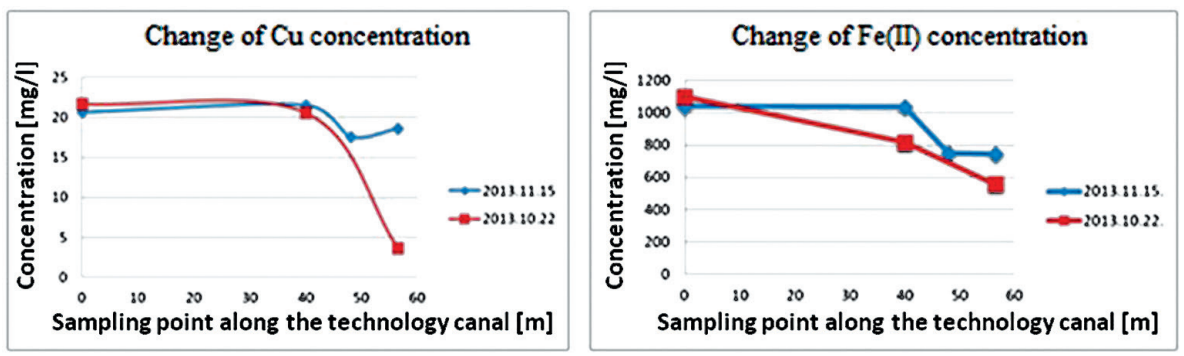

Fig. 11

Change of $\mathrm{Fe}$ (II) and $\mathrm{Cu}$ concentration along the channel in two testing time

contribute to this decreasing efficiency. As Fe (III) precipitates on the surface of limestone a crust is formed, blocking the neutralizing effect of the material. This has an impact on the adsorption capacity, as the acidic $\mathrm{pH}$ is not ideal for the adsorption on lignite.

The described crust formulation has a negative effect on the hydraulics of the entire system as well, although it did not cause any problem at this stage of the test operation. The team had to conclude that the neutralization of the AMD discharge must be implemented with some other mechanism, and is shifting the study into a new line of research.

\section{Calibration of infiltration model using ${ }^{3} \mathrm{H} /{ }^{3} \mathrm{He}$ dating of groundwater and natural tracer techniques}

Nowadays climate change creates extreme weather conditions, which has a significant impact on the natural water cycle. These effects exert strong influence on natural groundwater recharge, as well as the quantity and the quality conditions of the subsurface waters in the region of northern Hungary. Professionals should be aware of the changes in aquifers for safe drinking water supply. Due to the extreme weather conditions there is a chance of decreasing natural groundwater recharge rates, causing the overall usable groundwater resources to be at risk in the basins of the region. For the $5^{\text {th }}$ module of the WELLaHEAD project the task is to estimate the natural groundwater recharge by lab and field tests using commonly-applied environmental isotopes, especially ${ }^{3} \mathrm{H}$ and ${ }^{18} \mathrm{O}$ as radioactive and stable isotopes.

The Danube-Tisza-ridge is one of the largest recharge areas in Europe. The derived average groundwater recharge has been calculated to be $53 \mathrm{~mm} /$ year. Close to this natural environment, about $16 \mathrm{~km}$ away, is an agricultural field next to a larger city, Kecskemét, where artificial irrigation was carried out between the middle 70s and 80 s of the last century. This irrigation water was supposed to be free of tritium since it had been used for drinking, having been drawn from artesian wells. Afterward the contaminated domestic sewage water was treated and purified, and the field irrigated with it. The annual precipitation of this site is $506 \mathrm{~mm}$, while since 1974 


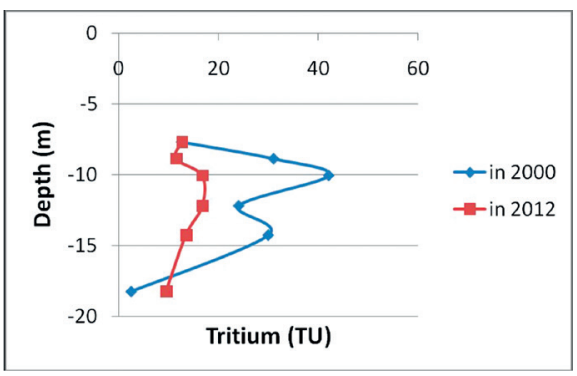

Fig. 12

Tritium profiles in the agricultural area taken in 2000 and 2012 about 300-400 mm/year water was used for irrigation. In 2000 a well-cluster with 6 wells was established in the site.

In May 2012 samples were taken for isotope-hydrologic investigations including ${ }^{3} \mathrm{H}$, noble gases, CFC's, stable isotopes, ${ }^{14} \mathrm{C}$ and water chemistry. The tritium bomb peak could be easily observed when looking at the tritium values determined in year 2000, but the effect of the tritium-free irrigation water could also be detected in the shape of the tritium peak.

From the two tritium profiles taken in 2000 and 2012 one can observe that the tritium concentrations of almost all groundwater samples have changed since 2000 (Fig. 12). The maximum values at 10 and $14 \mathrm{~m}$ depths have decreased, while in the deepest well the tritium level has risen. These effects can be explained on one hand by the hydrodynamic dispersion, and on the other by the radioactive decay of tritium. Hydrodynamic flow models will be used to reveal the natural groundwater movement, and what recharge rates are reliable for this field. To improve the age estimation of groundwater, we attempted to use ${ }^{3} \mathrm{H} /{ }^{3} \mathrm{He}$-dating of the water. However, the dissolved noble gases in the water samples show a degassed pattern, as if some of the noble gases had been lost. The lighter the noble gas the more significant the lack of the concentration: this is clear evidence that solubility-driven degassing is occurring in the aquifer.

This might happen when gas formation occurs in the saturated zone, and small noble gas free gas bubbles (e.g. nitrogen from denitrification) are entrapped between the soil particles. Under such circumstances noble gases dissolved in the groundwater are diffusing out to the gas phase until a new solubility equilibrium has been reached. The main problem with degassing effects is that ${ }^{3} \mathrm{H} /{ }^{3} \mathrm{He}$-dating cannot provide definite apparent water ages since it is not known how tritiogenic ${ }^{3} \mathrm{He}$ has been affected. If the degassing occurs at time zero $(\mathrm{t}=0)$, and then there is no further

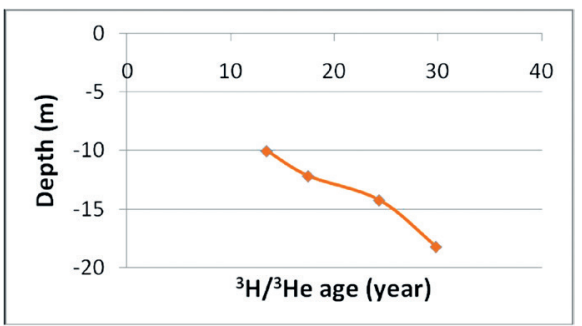

Fig. 13

Maximum ${ }^{3} \mathrm{H} /{ }^{3} \mathrm{He}$ apparent water ages

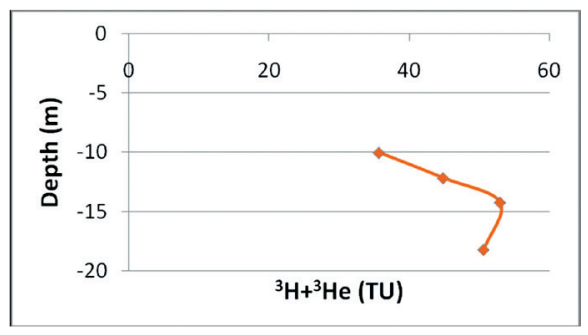

Fig. 14

The sum of ${ }^{3} \mathrm{H}$ and ${ }^{3} \mathrm{He}_{\text {trit }}$ in TU 
noble gas loss, all tritiogenic ${ }^{3} \mathrm{He}$ remain in the water phase. However, if degassing processes are occurring along the flow path, then the produced ${ }^{3} \mathrm{He}$ can escape from the water and a portion accumulates in the gas phase, which is not included in the groundwater samples. In this case two ${ }^{3} \mathrm{H} /{ }^{3} \mathrm{He}$ apparent water age can be provided, a minimum and a maximum age. Figs 13 and 14 show the maximum ages of the water, and the sum of the tritium and the tritiogenic ${ }^{3} \mathrm{He}$. These ages have been calculated under the assumption that the tritiogenic ${ }^{3} \mathrm{He}$ has suffered the same degassing pattern as the whole helium amount. It can be seen that the age increases with depth (which is what we expected). In addition, the sum of the tritium and the ${ }^{3} \mathrm{He}_{\text {trit }}$ reached the maximum values between 14 and $18 \mathrm{~m}$ of depth. This shows that the tritium bomb peak seems to be at this level.

\section{Conclusions}

The WELLaHEAD project is halfway toward implementing its goals, and in some R\&D activities we already see promising results. There is remarkable improvement in the Szerencs geothermal research and new development in other test sites. New scientific results and technical patents will be exploited as the research activity continues. Besides the technical and scientific results, an important aim of the project is to develop the research potential at the research unit, primarily at the University of Miskolc Department of Hydrogeology and Engineering Geology, with adjacent competences of the Faculty of Earth Science and Engineering. We also put a strong emphasis on networking activity, both in domestic and international scope. We expect that our success rate will increase in Framework program proposals, especially as we approach the Horizon 2020 calls. We seek possible collaborations with European research entities in joint proposals. The project will serve as a catalyst for collaboration between SMEs and the academic research communities. Those business entities that are invited into the collaboration can be our future R\&D contractors. Our special voluntary undertaking is to develop a new Knowledge Management Plan which highlights those channels through which the intellectual portfolio of the research team can be utilized on international markets.

\section{Acknowledgements}

The research was carried out within the framework of the Sustainable Resource Management Center of Excellence at the University of Miskolc as part of the TÁMOP4.2.2/A-11/1-KONV-2012-0049 "WELLaHEAD" project, within the framework of the New Széchenyi Plan, funded by the European Union and co-financed by the European Social Fund. 


\section{References}

Bőhm, J., Á. Debreczeni, I. Gombkötő 2003: PEREBAR - Innovative Groundwater remediation. - In: The Functioning and Management of the Water-Soil System at River Basin Scale: Diffuse Pollution and Point Sources. BRGM - Bureau de Recherches Géologiques et Mines, Water Cycle and Soilrelated Aspects EU-Workshop, Orléans, pp. 437-445.

Davison, W., H. Zhang 2012: Progress in understanding the use of diffusive gradients in thin films (DGT) - back to basics. - Environ. Chem., 9, pp. 1-13.

Fejes, Z., P. Szűcs, P. Szlabócky 2013: Hidrogeológiai kutatások a Tokaji-hegység déli részén (Hydrogeology research in the southern part of the Tokaj Mountains). - Elektronikus Müszaki Füzetek, pp. 67-73. (in Hungarian)

Lakatos, J., I. Szabó, B. Csőke, C.E. Snape 2007: Coals and biomass as active materials for permeable reactive barriers. - Anyagmérnöki Tudományok, 33, pp. 13-22.

Madarász, T., P. Szűcs, J. Lakatos, I. Gombkötő, J. Szántó, J. Radeczky, N. Trauer, B. Zákányi, I. Székely 2011: Újszerű reaktív gátak tervezése (Design of a new generation of permeable reactive barriers). Elektronikus Müszaki Füzetek, 9, pp. 1-10. (in Hungarian)

Miklós, G. 2003: Langyosvíz beszerzési lehetőségek Szerencs térségében (Potential warm water sources in the Szerencs region). - Geokomplex Kft., Miskolc. (in Hungarian)

Szűcs, P., B. Kovács, T. Madarász, L. Lénárt 2012: Kutatási terv, KÚTFŐ (Research Plan, KÚTFŐ). Manuscript, Miskolci Egyetem (in Hungarian)

Szűcs, P., Z. Fejes, K. Kormos 2013: Hidrogeophysical applications in the thermal water research of Szerencs. - Debreceni Müszaki Közlemények, 2013/2, 10 p.

Tóth, J. 1962: A theory of groundwater motion in small drainage basins in Central Alberta. - Journal of Geophysical Research, 67/11, pp. 4375-4387.

Tóth, J. 1978: Gravity-induced cross-formational flow of formation fluids, Red Earth region, Alberta, Canada: Analysis, patterns, evolution. - Water Resources Res., 14/5, pp. 805-843.

Tóth, J., I. Almási 2001: Interpretation of observed fluid potential patterns in a deep sedimentary basin under tectonic compression: Hungarian Great Plain, Pannonian Basin. - Geofluids, 1/1, pp. 11-36.

Turai, E., A. Kolencsik-Tóth, B. Kovács, T. Madarász, P. Szűcs 2014: A talajszennyezési csóvák kimutatásának új módszere az IP adatok Tau-transzformációjának alkalmazásával (New method for the characterization of soil contaminant plumes by Tau-transformation of IP data). - 10th Carpathian Basin Conference for Environmental Sciences, Cluj, Romania. (in Hungarian) 